\title{
Total Approach is a Must for Small and Medium Enterprises to Attain Sustainable Working Conditions and Environment, with Special Reference to Bali, Indonesia
}

\author{
Adnyana MANUABA \\ Department of Physiology, School of Medicine, University of Udayana, Jalan P B Sudirman, Denpasar, Bali, Indonesia \\ Received August 31, 2005 and accepted November 24, 2005
}

\begin{abstract}
Attention and assistance to enhance the role of small and medium scale enterprises (SMEs) by the government is more emphasized due to the success of SMEs in earning significant amount of foreign currency when Indonesia had to face economical crisis in 1997. This policy has been highly recognized again since the bombing tragedy in 2002; with the excellent evidence to show how important SMEs is in helping and maintaining the economic development of Bali. But in the implementation the assistance needs to be remanaged again in a more proper and appropriate way to attain the ultimate goals. The three economic potentials, agriculture in broad sense, tourism and SMEs (cottage industry included), must be developed in harmony, interdependence, support and complementary each other, if possible as synergist to obtain sustainable development of Bali. While assistance to SMEs must be done in a more coordinated way among the government technical offices, universities, NGOs, banking, and other social community institutions. By doing so, there would be no duplication or gap, nor creation of new disadvantageous problems. It could be in form of ergonomics, occupational health and safety impacts and problems in particular, and in adverse working conditions and environment in general. Therefore it is a must at this moment to carry out total approach in helping SMEs, by integrating the effort to improve their working conditions and environment, built-in within the effort to enhance SMEs'quality of life through economic assistance. In this process a total approach through SHIP approach and Appropriate Technology intervention must be done wisely and timely. By so doing, SMEs'sustainable working conditions and environment shall be attained.
\end{abstract}

Key words: Total Approach, SMEs, Sustainable improvement

\section{Introduction}

For years Small and Medium Scale Enterprises (SMEs) have been considered as resilient economic component of the country as it could absorb a lot of man power as well as its independent character to globalization impacts. Therefore a lot of assistances have been given to these SMEs ever since. Based on previous unpleasant experiences, a more serious attention and correct steps must be taken into consideration ${ }^{4,22,24,30,31,35,46-48,49)}$. As coordination lack has always been our obstacle and constraint to be successful, a serious holistic planning must be and become important issues to be concerned, committed and conducted ${ }^{1,2,4-7,9,10,14-16,26,29,33-35,43)}$. All assistances must be given in a very more coordinated way with aim to have maximal and optimal results, even if possible as synergist, especially in managing the growth and advancement of the three pillars economic potentials of Bali: agriculture, tourism and SMEs, for Bali's sustainable development ${ }^{8,12}$.

As all those processes shall be done within free global market, in which the product should also be competitive and accepted by the global development, concept with its various respected ISO must also be utilized ${ }^{1)}$.

This paper is trying to illustrate the total approach effort which has to be carried out to minimize the disadvantageous 
impacts which might emerge due to inappropriate and improper assistances given to SMEs, and helping its growth and advancement to be globally accepted.

\section{Materials and Methods}

Review based on years of experiences in doing research, services and training, as well as doing direct observation at plant level, in resolving their problems, in improving and encouraging policy and decisions made for SMEs'sustainable development, particularly in Bali.

\section{Results and Discussion}

For years with aim to help SMEs'capability and survival and their growth for advancement, various types of assistances have already been given by many government technical departments as well as by financial institutions/ banks, universities, NGOs and community service institutions. It is in form of capital loan, management and technical skill know-how, raw materials accessibility, occupational health-safety and ergonomics trainings and intervention, marketing assistance, obtaining better product and productivity, etc. But in fact, those efforts have not been done in a proper and appropriate way. Each party did it in its own way based on their duty and role with aim to be successful in their own program. There was no coordination in planning and implementation among them ${ }^{11,32-35,41-49)}$. It is understandable that there would be a lot of duplication and gap as well as idle outcome at the end. Very often, successful program of one party, created new problems and had to face by the others ${ }^{4-7)}$.

Additional problems also very often occurred as consequence of uncoordinated program done by university students during their ìstudent scheme program". This program is aimed to give students an opportunity to practice their theoretical knowledge and technical know-how in the real situation. Very often they attained their goal, but with additional problems left behind to the people/SMEs. And nobody cares about it, and the impacts finally have to be lifted by respected SMEs.

Similar mistakes were surprisingly made again when various parties through the so-called Social Network Safety scheme did a lot of financial help to SMEs, in which mismanagement was done intensively. Besides very often the assistances did not came to the right targets, it also has been given in inappropriate and improper ways. Besides idleness, the fund was also corrupted by various parties or individuals, although evidence based is very difficult to be shown. This happened when Indonesia had to face the 1997 economical crisis, during which the government decided to emphasize the role and function of the SMEs.

With the Bali bombing tragedy in 2002, the SMEs showed again their significant role to help Bali's economy. The collapse of tourism has been overcome by SMEs'product export drive to earn foreign currency. They also significantly showed how important their resilient character and role in development were as well. Therefore it is understandable that special attention and appropriate action must be done for their growth and advancement ${ }^{11}$.

Firstly, we have to go back to our previous agreement that the three economic potentials must be developed in harmony, interdependence, and support and complementary each other if possible as synergist, with which we started development planning and program in $1969^{12)}$. The mistake that one dominating sector could even inhibit the development of other sectors must not be done again ${ }^{3,34-49}$.

Then in carrying out the development efforts, through utilization of science and technology, it must be conducted through a total ergonomic approach to avoid the emergence of negative impacts, like complaints or feeling of pain, occupational related diseases, accidents, poisoning, pollution, environmental destruction or casualties. By total approach it means that the technology being used must be comprehensively assessed using 6 criteria: it whether or not technically, economically, ergonomically, and socioculturally sound, save energy, and whether or not preserve the environment. And in analyzing each criterion, a SHIP (Systemic, Holistic, Interdisciplinary and Participatory) approach must be utilized. In this context, principles of sustainability, competitiveness, productivity and product quality were strongly applied. Various related and significant ISO, TQM and their ergonomic strategies, must also be considered. By using this approach, the end result would be work system and product that are humane, competitive and sustainable ${ }^{29-33)}$.

This approach must be carried out by everybody who would like to help SMEs, for its successful result. In this context, proper and appropriate conducts must be done. First a more coordinated effort must be done by each party and then followed up by a total ergonomic approach. And as financial problems become SMEs first problem in priority, it would be strategically sound if the assistance could be "built-in" within the financial assistance given to them ${ }^{30}$. By so doing, financial problem as well as those of working conditions and environment could be simultaneously resolved.

To carry out this scenario, ones who could think and act holistically must be trained in various relevant sectors of development ${ }^{13-28)}$. Since 1999 , more than 3,500 people, representing the stakeholders of Bali, have been conditioned to obtain such capability through Integrated Ergonomic SHIP approach workshops. The general theme of the workshops is sustainable development of Bali, with various topics to be discussed. The output consists of "action plans" and the outcome is the "empowerment" of the participants, especially 
in thinking and acting holistically, besides enhancement of knowledge and technical know-how on carrying out democracy and human rights. Through this workshop, "experience", "expertise" and "perspective to look forward" were gathered together to be used to solve problems being raised as well as its additional value to be "bottom-up" and itop-down" processes in its discussion. With this approach, in holistic planning and weak law enforcement which become Baliís root cause of all development problems being faced up to now could be solved in a more conceptually and basically based ${ }^{8)}$.

Besides these workshops, which have been carried out 30 times to date, this concept of how to think and act holistically, has also been "built-in" within the postgraduate ergonomics program at Udayana University. It aims to prepare graduates on ergonomics who could think and act holistically beyond their ergonomic expertise, to serve for sustainable development of Bali in particular and the world in general ${ }^{9}$.

A model sustainable development village by name of Petiga, at Tabanan regency, Bali, has also been developed, in which the three economic potential factors of Bali have been developed in harmony. In doing so a Total Ergonomic approach has been implemented in its development and advancement. Petiga shall become a model village where agriculture, tourism and small scale cottage industry is really functioning in harmony. And all work system and product shall be humane, competitive and sustainable, which will be obtained within and through a health, safety, comfort and efficient working conditions and environment.

And all the above conduct has been practically legalized by the issued People Consultative Assembly Act, No 4/MPR/ 1999 which was more popular as the State Macro Development Guideline 1999-2004, which said that "Tourism Development must be done in holistic, interdisciplinary and participatory system, through comprehensive assessment of economical, technical, ergonomical, socio-cultural, energy-saving, and environmental criteria". Although it related to tourism development but its mind and soul could be used to any developmental process ${ }^{50)}$. In addition, Act No 13/2003, which said in general that in any enterprise OHS principle and concept must be carried out, also supported the implementation of the above idea.

\section{Conclusion}

To enhance the quality of life of the people in general, SMEs in particular, especially to minimize disadvantageous impacts to occur in the application of science and technology, a total ergonomic approach must be carried out in helping those to grow and advanced. It means that the technology being used or chosen, must be assessed comprehensively through six criteria, namely, whether or not technically, economically, ergonomically, socio-culturally sound, safe energy and preserve and whether not destruct the environment. In doing so, a SHIP (systemic, holistic, interdisciplinary, participatory) approach must be conducted in the analyzing process. To accelerate the program to be successful, the program must be "built-in" implemented within the financial assistance given to SMEs for its advancement.

As coordination lack and shortage always occurred until recently in helping the SMEs, coordination step has become a must. All program assistances from various parties must be able to be coordinated from the planning stages up to their implementation, and this task must be able to be conducted by ones who have the capability to think and act holistically. Integrated Ergonomic SHIP approach workshop is the way to do so, in which through conditioning process, ones are taught how to think and act holistically. Similar approach has also been "built-in" within the curriculum of postgraduate program of ergonomics at Udayana University ${ }^{9)}$. A model village in terms of sustainable ergonomics, by name of Petiga, has started to show how the three economic potentials of Bali could be developed in harmony, by having a sustainable working conditions and environment and humane, competitive and sustainable work system and product. And the above idea has been legalized by the issuance of the Act No 4/MPR/RI 1999 and Act No 13/2003 ${ }^{50)}$.

\section{References}

1) Manuaba A (2004) Designing humane, competitive and sustainable work system and product. Presented at the National Seminar on Ergonomics, Aplikasi Ergonomi di Industri, UPN, 27 March, Yogyakarta.

2) Manuaba A (2004) Holistic ergonomics approach is a must in automation to attain humane, competitive and sustainable work process and products. Presented at the National Ergonomics Seminar, Application of Ergonomics in Industry, UPN, 27 March, Yogyakarta (in Indonesian).

3) Manuaba A (2004) Ergonomics contribution in development, with special reference to Bali. Presented at 2nd National Ergonomics Seminar, UGM, 9 October, Yogyakarta (Indonesian).

4) Manuaba A (2004) Total approach is a must for small and medium enterprises to attain sustainability working conditions and environment, with special reference to Bali Indonesia. Presented at the International Symposium on Occupational Health in Small-Scale Enterprises and the Informal Sector, 12-15 November, Nagoya.

5) Manuaba A (2003) Holistic design is a must to attain sustainable product. Presented at the National Seminar on Product Design and Development. Industrial Engineering UK Maranata, 4-5 July, Bandung.

6) Manuaba A (2003) Holistic approach of ergonomics application is a must, to attain more sustainable results 
and competitively sound. Presented at the Scientific Meeting and National Assembly of Occupational Health, Safety and Ergonomics. 17-19 July, Jakarta (in Indonesian).

7) Manuaba A (2003) A systemic, holistic, interdisciplinary and participatory (SHIP) approach to ergonomics problems and solutions. Presented at the 15th Triennial Congress of the International Ergonomics Association (IEA), 24 29 August, Seoul.

8) Manuaba A, (2003) Through Integrated Ergonomics "SHIP" Approach Workshops, Bali-HESG Contribute to the Achievement of Sustainable Development of Bali. Presented at the 15th Triennial Congress of the International Ergonomics Association (IEA), 24-29 August, Seoul.

9) Manuaba A (2003) Better Horizon and conducting holistic approach are a must for the students of the postgraduate study program on ergonomics at Udayana University to be fit and proper in doing their tasks. Presented at the 15th Triennial Congress of the International Ergonomics Association (IEA), 24-29 August, Seoul.

10) Manuaba A (2003) There are still some obstacles and constraints in implementing action plans as the output of integrated ergonomics SHIP approach. Workshops carried out in Bali. Presented at the SEAMEC 2003 and the 7th SEAES Conference, 24-28 May, Kuching, Malaysia.

11) Manuaba A (2003) How far the changes could be tolerated? In: Proceeding of the International Seminar and Workshop on Traditional Culture in a Changing World. 1-3, 19-20 April, Denpasar, Indonesia.

12) Manuaba A (2003) Total ergonomic approach to enhance and harmonize the development of agriculture, tourism, and small scale industry, with special reference to Bali. Presented at the National Congress and Seminar of the Indonesian Ergonomics Association (PEI), 13 September, Yogyakarta.

13) Manuaba A (2003) Work organization, ergonomics and productivity. Presented at the National Ergonomics Seminar, 9-10 April, Jakarta (in Indonesian).

14) Manuaba A (2003) Holistic ergonomics design as a strategy to integrate occupational safety-health system management into the Enterprises system management. Presented at the 2nd NIEC (National Industrial Engineering Conference), Surabaya University, 10 October, Surabaya, East Java.

15) Manuaba A (2002) SHIP approach workshop on democracy and human right. An example of how ergonomics has been effectively integrated within its process. Presented at the National and International Seminar on Ergonomics, 1317 October, Bali, Indonesia.

16) Manuaba A (2002) Integrated ergonomics "SHIP" approach is a must in designing night and shift work in developing countries, with special reference to Bali, Indonesia. Presented at International Symposium on Night and Shift Work, Hayama, Japan.

17) Manuaba A (2002) Traditional culture in a changing world, an introduction paper. In: Proceeding of the NationalInternational Seminar on Traditional Culture in a Changing World. 1-4, 22 March, Denpasar, Indonesia.

18) Manuaba A (2002) Balinese women, their domestic and occupational working conditions and environment. Presented at the International Congress on Women, Work and Health, 2-5 June, Stockholm.

19) Manuaba A (2001) A change of the human behavior is a must to start management of change, special experience with the integrated ergonomics SHIP approach workshops. In: Proceeding of the 1st National Industrial Engineering Conference. Department of Engineering, University of Surabaya, Surabaya, A30-3.

20) Manuaba A (2001) Ergonomics approach in tourism development is a must in indonesia, a challenge and an opportunity for ergonomist? In: Proceeding of National and International Seminar on Ergonomics-Sport Physiology, 11-12 July, University of Udayana. Udayana University Press, Bali.

21) Manuaba A (2001) Unergonomic design of information means in denpasar, beside idle, could created also negative impacts? In: Proceeding of National and International Seminar on Ergonomics-Sport Physiology, 11-12 July, University of Udayana. Udayana University Press, Bali.

22) Manuaba A (2001) Planning aspect in ergonomics lecture in front of technical students. TI-Fakultas Teknik Ubaya, 8 June, Surabaya (in Indonesian) .

23) Manuaba A (2001) Ergonomics approach in organizing a conference is a must to attain optimal goals. In: Proceeding of National-International Seminar on Ergonomics and Sport Physiology. 1-4, Udayana University Press, Bali.

24) Manuaba A (2001) Research and application of ergonomics in developing countries, with special reference to Indonesia. J Ergonomic Indonesia 1, 24-30.

25) Manuaba A (2001) Changing role of physiologists to cope with a changing world. Presented at the 12th National Seminar on Physiology, 27-8 April, Batu, Malang.

26) Manuaba A (2000) Application of integrated ergonomics and Ship approaches in resolving sustainable development problems in Bali, Indonesia. In: Proceeding of Joint Conference of APCHI 2000 and ASEAN Egonomics 2000. 399-403, Elsevier Science Ltd., Amsterdam.

27) Manuaba A (2000) Mutual Benefit ergonomics cooperation: a must in Southeast Asia and the Pacific region. In: Proceeding of Joint Conference of APCHI 2000 and ASEAN Ergonomics 2000. 264-9, Elsevier Science Ltd., Amsterdam.

28) Manuaba A (1999) Working conditions and environment in Indonesia. Presented at the 1st Workshop on Heat Stress and Physical Workload, 2-5 February, Bangkok.

29) Manuaba A (1999) Participatoric ergonomics approach application in enhancing industrial performance. Presented at the Seminar Nasional Ergonomi, Re-evaluation of Ergonomics Implementation in Enhancing Industrial Performance, 23 November, Surabaya, Indonesia.

30) Manuaba A (1998) Appropriate technology approach with its "built-in" ergonomics aspect is a must in technology transfer to attain sustainable development in industrially developing countries. In: Global Ergonomics. 57-62, Elsevier Science Ltd., Amsterdam.

31) Manuaba A (1998) Task demands, working capacity and performance. A holistic system approach in manual 
material handling. In: Proceeding of One Day Seminar on Ergonomics and Sport Physiology, Denpasar, Bali, Indonesia.

32) Manuaba A (1998) Widen the Horizon is still needed in Ergonomics approach and application in Indonesia. In: Proceeding of One Day National Seminar on Ergonomics and Sport Physiology. 245-9, 18 November, Denpasar, Bali, Indonesia.

33) Manuaba A (1997) Holistic approach is a must in solving ergonomics problems in construction sectors in Bali. Presented at the 13th Triennial Congress of the International Ergonomics Association, Tampere, Finland.

34) Manuaba A (1997) A holistic change approach is a must to face global competition. Bali's experience. Presented at the 13th Triennial Congress of the International Ergonomics Association, Tampere, Finland.

35) Manuaba A (1997) Total approach is a must to attain sustainable improvement in small scale and cottage industry. Presented at WHO International Conference on Occupational Health in Informal Sectors, Denpasar, Indonesia.

36) Manuaba A (1977) Choice of technology and working conditions in rural area. Presented at the Phillipines PIAC Seminar, Manila, Phillipines.

37) Manuaba A (1997) Ergonomic challenges in the South East Asia Region, a vision to 21st decade. Presented at the 5th SEAES Conference, Kuala Lumpur, Malaysia.

38) Manuaba A (1996) Ergonomics is a must to face global competition in hotel business. Presented at Pan Pacific Conference on Occupational ergonomics, Taipei, Taiwan.

39) Manuaba A (1996) Different feature of work systems in Indonesia and its consequent approach. Presented at International Symposium on Different Feature of Work Systems, Yokohama, Japan.

40) Manuaba A (1996) Ergonomic is a must to face global competition in hotel business. Presented at Pan Pacific Conference on Occupational Ergonomics, Taipei, Taiwan.
41) Manuaba A (1995) Bali: Enhancing the image through more effective planning. In: Bali, Balancing Environment, Economy and Culture. eds. by Martopo S and Mitchell B, 29-42, Department of Geography, University of Waterloo, Canada.

42) Manuaba A (1995) Enhancing the Culture. In: Bali, Balancing Environment, Economy and Culture. eds. by Martopo S, Mitchell B, 521-34, Department of Geography University of Waterloo, Canada.

43) Manuaba A (1994) Appropriate technology choice and transfer is a must for sustainable development in Asia, with special reference to Indonesia. Presented at Asian Studies Association Annual Conference, Perth, Australia.

44) Manuaba A (1991) Developing ergonomics sound technology transfer from Japan to ASEAN countries. The role of ergonomics societies. Presented at 11th Triennial Congress of the International Ergonomics Association, Paris.

45) Manuaba A (1987) Twenty years working in ergonomics. Presented at National Ergonomics Conference, Bandung, Indonesia (Indonesian).

46) Manuaba A (1981) The role of ergonomics at national develoment. Presented at 3rd National Congress of Science, Jakarta.

47) Manuaba A (1979) Ergonomics and development in Bali. Presented at Symposium Ergonomics in Tropical Agriculture and Forestry. Wagenigen, the Netherland.

48) Manuaba A (1978) Integration of work physiologyergonomics in development policy. Oration as Professor, Denpasar, Indonesia.

49) Manuaba A (1973) Potential role of ergonomics in national development. Presented at 7th Asian Conference on Occupational Health, Jakarta, Indonesia.

50) People Representative Assembly of the Republic of Indonesia Act (1999) TAP MPR, NO 4/MPR-RI/1999, on National Development Greatline. 